\title{
Ustalenie granicy Węgier z Chorwacją i Serbią po I wojnie światowej ${ }^{1}$
}

Zarys treści: Znaczący udział dywizji serbskich w zwycięskiej ofensywie Frontu Salonickiego zaowocował postanowieniami Konwencji Belgradzkiej z 13 listopada 1918 roku. Umożliwiły one Zgromadzeniu Narodowemu Słowian w Nowym Sadzie przyjęcie Oświadczenia o przyłączeniu Baranii, Bački i Banatu, czyli krain Vojvodiny do Królestwa Serbii. W grudniu 1918 r. do swojego państwa Chorwaci przyłączyli również Međimurje. Ostateczny szczegółowy przebieg granic węgiersko-jugosłowiańskich został określony w traktacie podpisanym w Trianon 4 czerwca 1920 roku.

Słowa kluczowe: I wojna światowa na Bałkanach, Kapitulacja Austro-Węgier, Konwencja Belgradzka 13 listopada 1918, traktat w Trianon, Međimurje, Vojvodina, Baranja, Bačka, Banat, Bunjevci, Šokci, Królestwo Jugosławii

Key words: World War I, Balkans, The Armistice of villa Giusti 3 November 1918, Belgrade Convention 1918, Treaty of Trianon, the Bunjevac Ethnic Minority, The Kingdom of Yugoslavia

Wymieniony w tytule problem stanowi integralną część składową powiązanych ze sobą ogólniejszych kwestii, ważnych dla procesu historycznego nie tylko tego regionu, gdzie Europa Środkowa styka się z Bałkanami Zachodnimi, ale także dla całej Europy. Kształtowanie się granic węgiersko-jugosłowiańskich po I wojnie światowej było bowiem wynikiem a jednocześnie elementem powiązanych wielu wydarzeń w Europie i basenie naddunajskim, które spowodowały w konsekwencji rozpad całej monarchii Habsburgów i stanowiącego jej część Królestwa Węgierskiego - struktur państwowych obejmujących prawie całą Europę Środkową, zbudowanych

${ }^{1}$ Poprzednie publikacje poświęciłam oderwaniu się od Węgier Słowacji i słoweńskiego Prekmurja oraz pokazaniu kształtowania się granic węgiersko-słowackiej i węgiersko-słoweńskiej: R. Zawistowska, Demografia i rozmieszczenie ludności węgierskiej w Słowacji 1918-1950, „Studia z Dziejów Rosji i Europy Środkowo-Wschodniej”, t. XLVI, 2011, s. 99-126; eadem, Prekmurje - oderwanie od Wegier i przyłaczenie do Słowenii (1919-1920), „Studia z Dziejów Rosji i Europy Środkowo-Wschodniej”, t. XLVII, 2012, s. 49-75. 
i do końca swojego istnienia w znacznym stopniu opartych na feudalnych zasadach organizacyjnych, politycznych, społecznych i narodowościowych. Ważnym celem podjętych badań - może jeszcze ważniejszym od zmiany granic - jest zatem próba pokazania, w jakim stopniu narody południowych Słowian - i to nie tylko Serbowie, Chorwaci i Słoweńcy - przyczyniły się do rozpadu już starych form ustrojowych w Europie Środkowej i jaki wniosły wkład w zapoczątkowanie procesu historycznego kształtującego nowoczesne stosunki między narodami i państwami w tym regionie Europy.

Pod względem geograficznym rozważania dotyczą całej Chorwacji jako państwa położonego na Bałkanach Zachodnich na styku z Europą Środkową i Vojvodiny ${ }^{2}$, znajdującej się w granicach Serbii i zajmującej południową część Niziny Panońskiej. Terytorium Vojvodiny stanowi obszar największego obniżenia Niziny Panońskiej, do którego zmierza Dunaj i jego największe dopływy ${ }^{3}$, niosące wody z Alp (Drawa i Sawa), Gór Dynarskich (Drina), Niskich Tatr i całej wschodniej części węgierskiego Nagyalföldu (Wielka Nizina), a także z Karpat Wschodnich (Tisa z jej dopływami m.in. Maruszą). Ten nizinny region pod względem geograficznym stanowi wyraźnie odrębną całość, podzieloną przez wielkie rzeki na krainy geograficzno-historyczne.

Kwerenda została przeprowadzona w literaturze i materiałach źródłowych w wielu językach. Najważniejszym dokumentem jest tekst traktatu podpisanego w pałacu Trianon 4 czerwca 1920 roku$^{4}$. Niezbędne było dotarcie również do innych ważnych umów, porozumień i deklaracji m.in. tekstu ugody chorwacko-węgierskiej z 1868 r., uchwały parlamentu (saboru) Królestwa Chorwacji i Slavonii, deklaracji Rady Narodowej Państwa SHS z 29 października 1918 r., porozumienia belgradzkiego z 11 listopada 1918 r. deklaracji uchwalonej przez Wielkie Zgromadzenie w Nowym Sadzie 25 listopada 1918 roku.

Poza publikacjami polskimi, chorwackimi, serbskimi i węgierskimi pomocne okazały się opracowania angielskie, francuskie, rosyjskie ${ }^{5}$, a nawet hiszpańskie.

Poznawanie węgierskiego stanowiska wobec omawianej problematyki najlepiej rozpocząć od publikacji i działalności Oskara Jásziego, węgierskiego badacza społecznego, historyka i polityka, autora koncepcji środkowoeuropejskiego, naddu-

${ }^{2}$ Nazwa Vojvodina nie może być tłumaczona na język polski jako województwo. W Serbii vojvoda to najwyższy stopień wojskowy równy marszałkowi, a Vojvodina była traktowana jako prowincja o uprawnieniach księstwa, palatynatu lub banatu, ciesząc się dużym stopniem samodzielności. Została utworzona w okresie Wiosny Ludów z części Śremu i Baranii oraz Bački i Banatu. Od czasu wyparcia z tych krain Turków przez Austrię w końcu XVII i na początku XVIII w. znajdowały się one bezpośrednio pod jej administracją. Wzdłuż południowej granicy Austria zorganizowała Militarne Rejony Frontowe, gdzie osiedlała wielu Serbów.

${ }^{3}$ Po zebraniu tej olbrzymiej ilości wód Dunaj przebija się z tego obniżenia przez tzw. Żelazne Wrota na granicy Serbii i Rumunii i płynie dalej na wschód w kierunku Morza Czarnego.

4 Treaty of Peace Between The Allied and Associated Powers and Hungary And Protocol and Declaration, Signed at Trianon June 4, 1920.

${ }^{5}$ Н. Г. Корсун, Балканский фронт мировой войны 1914-1918 г2. - М.: Воениздат НКО СССР, 1939, http://militera.lib.ru/h/korsun_ng4/index.html [28.07.2013]. 
najskiego federalizmu ${ }^{6}$. Przez kilka tygodni podejmował on próbę wprowadzenia w życie tych koncepcji, wchodząc jako minister bez teki do utworzonego 31 października 1918 r. rządu Mihálya Károlyiego ${ }^{7}$.

Z opracowań polskich największy związek z omawianą problematyką ma napisana przez Tadeusza Kopysia rozprawa poświęcona biografii Oskara Jásziego i jego koncepcjom federalizmu naddunajskiego ${ }^{8}$.

Interesujące publikacje można znaleźć w prasie. Serbskie „Wieczernie Nowosti” w kolejnych numerach, poczynając od 1 grudnia 2008 r., zamieściły 17 obszernych felietonów pod ogólnym tytułem Polemike o Solunskom Frontu. Felietony były formą dyskusji nad problematyką książki profesora Dragoljuba R. Živojinovića, Nevoljni ratnici-velike sile i Solunski front 1914-1918. Już w pierwszym felietonie opublikowanym 1 grudnia zaakcentowano zamieszczoną w książce konstatację, że Francja i Anglia nie chciały rozpadu monarchii Habsburgów, a drogę do powstania Jugosławii otworzył wojenny triumf Serbii ${ }^{9}$. Dużo materiału o wydarzeniach w całej Vojvodinie w $1918 \mathrm{r}$. można znaleźć w miesięczniku „Bunjevačke novine”, wydawanym od 2005 r. w Suboticy przez Radę Narodową Bunjevackiej mniejszości narodowej (Nacionalni savet bunjevačke nacionalne manjine, ang. National Council of the Bunjevac Ethnic Minority).

\section{Kontekst historyczny zmiany południowej granicy Węgier po I wojnie światowej}

Kwerenda w źródłach i obfitej literaturze historyków mediewistów ${ }^{10}$, etnografów i językoznawców pozwoliła uzyskać względnie klarowny obrazu sytuacji demograficznej obszaru, który jest przedmiotem rozważań w prezentowanej publikacji od czasów rzymskich do I wojny światowej w XX wieku. Od VI w. na omawianym terenie południowej części Niziny Panońskiej przebywali Słowianie. Przejściowo byli tam również Goci, Gepidowie, Longobardowie, Awarowie, a w ostatnim piętnastoleciu IX w., kończąc wielką wędrówkę ludów w Europie, przybyli Węgrzy, także poszukujący miejsca do stałego osiedlenia. Przez kilka wieków obszarowi temu zagrażała Turcja, a po bitwie pod Mohaczem w $1526 \mathrm{r}$. opanowała go na blisko trzy stulecia.

Nowy etap w historii tego obszaru rozpoczął się na przełomie XVII i XVIII wieku. Klęska Turcji pod Wiedniem w 1683 r. zapoczątkowała wypieranie jej z basenu naddunajskiego i umacnianie się tam Cesarstwa Austriackiego. Baranię Austriacy zajęli w 1687 r., Bačkę w 1699 r., a na podstawie pokoju z 1718 r. (Der Friede von

6 T. Kopyś, Oszkár Jászi. Z dziejów idei federalizmu w Europie Środkowej w latach 1900-1920, Kraków 2006, ss. 192. Opracowałam obszerną recenzję tej pracy z uzupełnieniami o najnowsze opracowania węgierskie. Vide: (Rec.: R. Zawistowska, [w:] Polityka i Bezpieczeństwo, red. nacz. A. Adamczyk, t. II, Piotrków Trybunalski 2011, s. 260-268.)

7 A. Essen, Polityka Czechosłowacji w Europie Środkowej w latach 1918-1932, Kraków 2006, s. 16-17.

8 T. Kopyś, op. cit., ss. 192.

9 Mali na lomači velikog, „Вечерње Ноboctu” (online), 1 decembar 2008,http://www.novosti.rs/ dodatni_sadrzaj/clanci.119.html:279424-Mali-na-lomaci-velikog-rata [28.07.2013].

10 A. Ivić, Istorija Srba u Vojvodini, Novi Sad 1929; D. M. Lang, Bułgarzy, Warszawa 1983; T. Wasilewski, Historia Bułgarii, Wrocław 1988; Vide: R. Zawistowska, Prekmurje..., s. 51-54 (nie wymieniam tutaj opracowań wzmiankowanych w poprzedniej mojej publikacji). 
Passarowitz) ${ }^{11}$ również Temescher Banat (węg. Temesi Bánság). Barania, Bačka i obszar położony między Dunajem, Cisą i Maruszą, czyli Banat, znajdowały się do 1860 r. pod bezpośrednią administracją austriacką. Nad Dunajem wzdłuż południowych granic ciągnął się pasem wojskowy Military Frontier.

Po wiekach panowania tureckiego liczba ludności była niewielka, ale systematycznie się zwiększała. Przybywali Serbowie osadzani najczęściej w sektorach frontowych (Military Frontier) ${ }^{12}$. Szybko rosła liczba Niemców, znacząco zwiększyła się także liczba Słowaków ${ }^{13}$. Największym bogactwem tych krain była ziemia, na której Cesarstwo Austriackie tworzyło olbrzymie latyfundia dla przedstawicieli austriackich magnackich rodów książęcych i hrabiowskich. Otrzymywali je również popierający cesarza magnackie rody węgierskie.

Pod wpływem wydarzeń Wiosny Ludów cesarz austriacki 18 listopada $1849 \mathrm{r}$. podpisał patent o utworzeniu Woiwodschaft Serbien und Temeser Banat - jednostki administracyjnej o statusie prowincji (księstwa) i dużych kompetencjach autonomicznych. Władzę w prowincji w imieniu cesarza sprawował gubernator, wielki książę, mający siedzibę w Timisoarze ${ }^{14}$.

Ogólna liczba ludności Wojwodiny i Banatu w 1860 wynosiła 1,5 miliona osób ${ }^{15}$, w tym 422000 Rumunów, 385000 Serbów, 368000 Niemców, zwłaszcza w Dunajskiej Szwabii, i 268000 Węgrów. Według źródeł serbskich w 1860 r. Serbów było 432 523, 414490 Rumunów, 396156 Niemców i 256164 Węgrów $^{16}$.

Osłabienie Austrii w wyniku przegranych wojen z Francją i Piemontem w 1860 r., a następnie z Prusami w $1866 \mathrm{r}$. Węgrzy umiejętnie wykorzystali, poprawiając swoją pozycję w habsburskiej monarchii ${ }^{17}$. W ramach tych ustępstw w październiku $1860 \mathrm{r}$. cesarz zlikwidował autonomiczne uprawnienia prowincji Wojwodina i Banat. Drugi krok został zrobiony 27 grudnia 1860 roku. Całą prowincję cesarz przekazał pod jurysdykcję Królestwa Węgierskiego. Dotychczasowa autonomiczna prowincja została podzielona na cztery komitaty: Bacs-Bodrog, Torontál, Temes i Krassó-Szörény ${ }^{18}$.

${ }^{11}$ Pokój ten odbierał zarazem wszelkie nadzieje Franciszkowi II Rakoczemu, kierującemu od 1703 r. antyhabsburskim powstaniem, i oznaczał zupełne podporządkowanie Węgrów cesarzowi. Vide: Franciszek II Rakoczy, Pamiętniki - Wyznania, wybrał, opracował i wstępem zaopatrzył J. R. Nowak, Warszawa 1988, ss. 448, Biblioteka Pamiętników Polskich i Obcych, red. Z. Paczoska, seria pod red. Zofii Lewinówny.

12 M. Tutorov, Banatska rapsodija - istorika Zrenjanina i Banata, Novi Sad 2001.

13 J. Sirácky, Stahovanie Slovákov na Dolnú zem v 18 a 19 storočí, Bratislava 1966, s. 93.

${ }^{14} \mathrm{~K}$. Clewing, Die doppelte Begründung der serbischen Wojwodschaft 1848-1851. Ethnopolitik im Habsburgerreich, [w:] K. Clewing, O. J. Schmitt, Südosteuropa. Von vormoderner Vielfalt und nationalstaatlicher Vereinheitlichung. Festschrift für Edgar Hösch. (=Südosteuropäische Arbeiten, Band 127) München 2005, s. 253-302; M. Palić, Srbi u Mađarskoj. Ugarskoj do 1918, Novi Sad 1995, s. 285.

${ }^{15}$ H. A. Pierer, Universal-Lexikon der Gegenwart und Vergangenheit, t. 15: Serbische Wojewodschaft u. Temeser Banat (Wojewodschaft S. u. Temeser Banat), Altenburg 1862, s. 883.

${ }^{16}$ M. Palić, op. cit., s. 285.

17 Chociaż z małą przerwa w latach 1861-1864. Vide: J. Kochanowski, Węgry. Od ugody do ugody1867-1890, Warszawa 1997, s. 20.

${ }_{18}$ M. Tutorov, Mala Raška u Banatu, Zrenjanin 1991; idem, Banatska rapsodija - istorika Zrenjanina i Banata, Novi Sad 2001. 
Wschodni Śrem został przyłączony do już istniejącego węgierskiego komitatu Szerém ze stolicą w Vukovarze.

Mapa 1. Prowincja Vojvodina i Banat 1848-1860

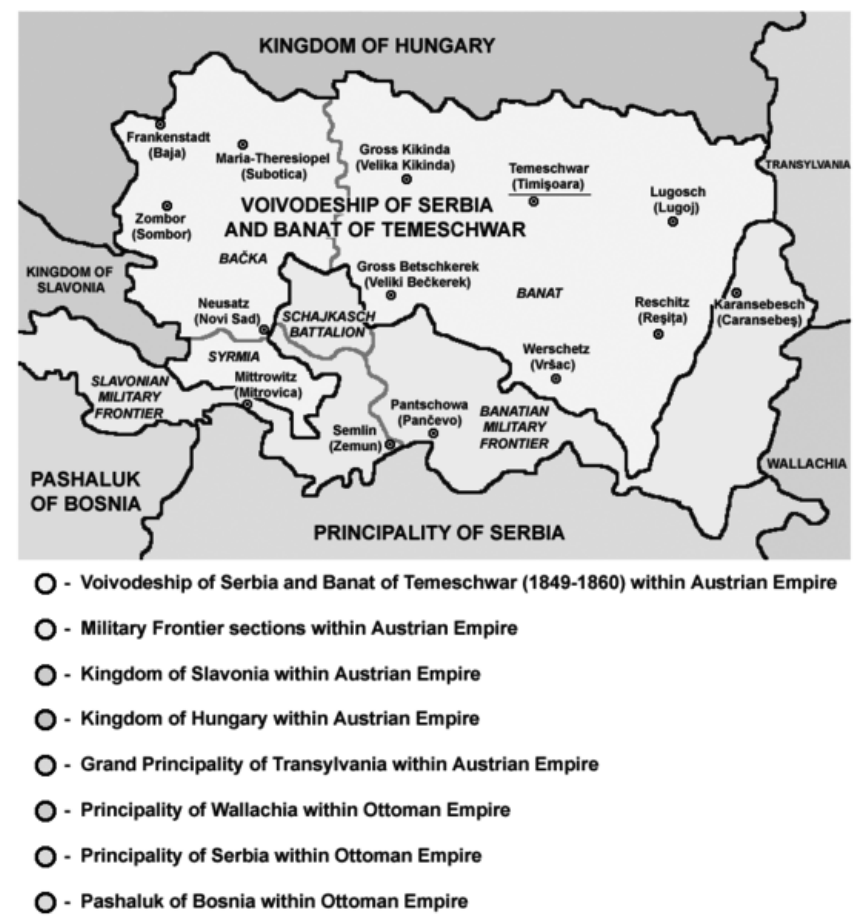

Źródło: Această operă a fost eliberată domeniului public de către autorul său, PANONIAN. Aceasta se aplică inintreaga lume. In anumite țări există posibilitatea ca acest lucru să nu fie legal posibil; in acest caz: PANONIAN permite oricui să utilizeze această operă în orice scop, fără nicio condiție, atâta timp cât asemenea condiții nu sunt cerute de lege. http:// es.wikipedia.org/wiki/Vojvodina, File: Vojvodinamapa.png [28.07.2013].

W komitatach utworzonych na terenie Banatu przeważała ludność rumuńska, szczególnie w komitacie Krassó-Szörény. W 1910 r. mieszkało w nim ogółem 466147 osób, w tym: 336082 (72\%) Rumunów, 55883 (11\%) Niemców, 33787 (7,57\%) Węgrów, 14674 (3,28\%) Serbów i 2908 (0,65\%) Słowaków. W komitacie Temes w 1910 r. mieszkało 500835 osób, w tym: 169030 (33\%) Rumunów, 165883 (33\%) Niemców, 79960 (15\%) Węgrów, 69905 (13\%) Serbów i 3080 Słowaków ${ }^{19}$. Inaczej już układały się proporcje w komitacie Torontál w zachodniej części Banatu. W 1910 r. mieszkało w nim ogółem 615151 osób, w tym: 199750 (32\%) Serbów, 165779 (26\%) Niemców, 128405 (20\%) Węgrów, 86937 (14\%) Rumunów, 16143 Słowaków i 4203 Chorwatów²0.

19 S. Borovszky, Magyarország vármegyéi és városai. Temes vármegye és Temesvár, 1914.

20 Ibidem. 
W kwestii identyfikacji narodowej i poczucia tożsamości ludności serbskiej i chorwackiej szczególnie ważną rolę odgrywały Śrem i Slavonia. W Sirmium, stanowiącym obecnie część serbskiej Śremskiej Mitrowicy, papież Hadrian II w 869 r. ulokował słowiańskie arcybiskupstwo. Pierwszym arcybiskupem ustanowił w nim słowiańskiego misjonarza św. Metodego. Josip Juraj Strossmayer (Chorwat) mianowany w 1849 r. biskupem w slavońskim pobliskim Đakowie propagował w liturgii obrządek słowiański nazywany też cyrylo-metodiańskim i unię kościoła rzymskokatolickiego z prawosławiem. Wybudował obszerną bazylikę w Đakowie, gdzie nabożeństwa były odprawiane $\mathrm{w}$ tym obrządku ${ }^{21}$. Na biskupa Strossmayera był wywierany nacisk ze strony Watykanu i austriackich hierarchów kościoła katolickiego ${ }^{22}$. Obrządek cyrylo-metodiański utrzymał się nie tylko w Śremie i Slavonii. Nie udało się wprowadzić w życie zakazu odprawiania nabożeństw w języku starocerkiewnym także na terenie arcybiskupstwa w Splicie. Wielu Chorwatów traktowało utrzymanie tego porządku jako jeden z ważnych elementów obrony i kształtowania tożsamości i identyfikacji narodowej ${ }^{23}$.

Fot. 1 i 2 . Wejście główne i wnętrze Bazyliki św. Piotra w Đakowie
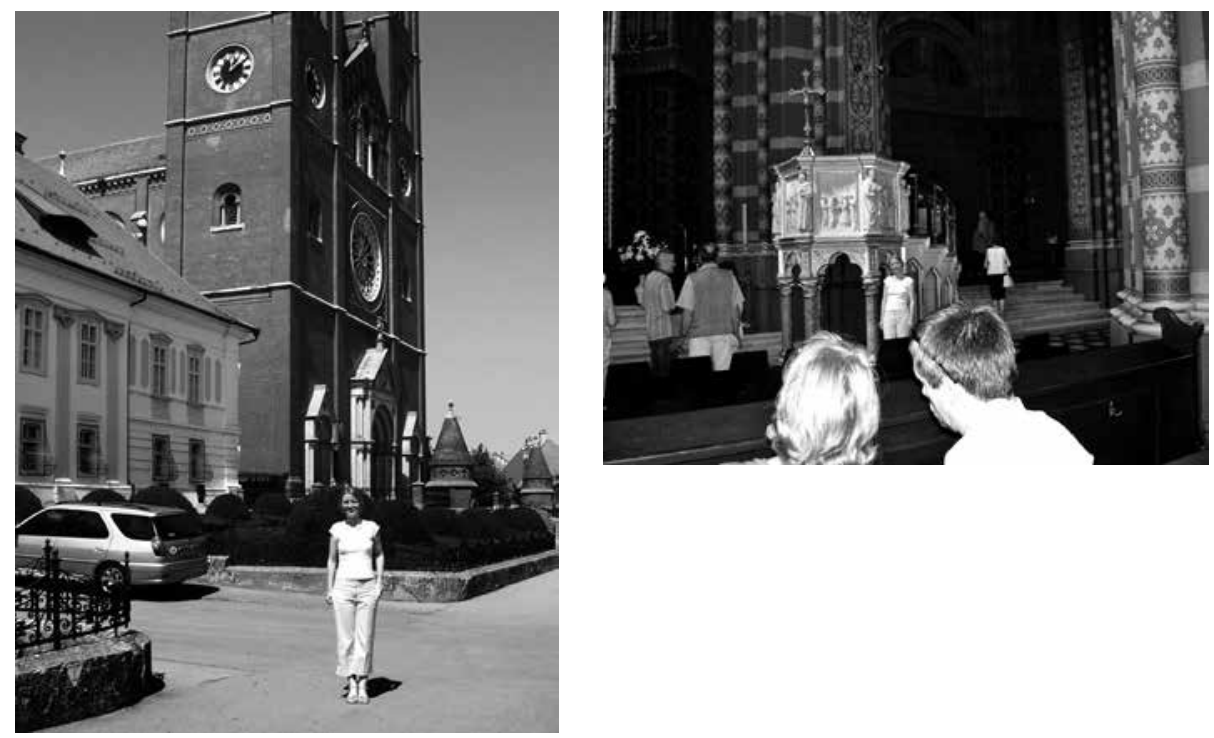

Źródło: Fot. 1 i 2. Zbiory własne (fot. J. Zawistowski 20.08.2006).

${ }^{21}$ B. Gavranović, Dr. Josip Juraj Strossmayer, Beograd 1935. N. Ikić, J. J.Strossmayer i crkveno, kulturno i nacionalno jedinstvo (J. J. Strossmayer und die kirchlich-kulturelle und nationale Einheit), Sarajevo 2002.

22 J. Oberški, Govori Strossmayera biskupa Đakova kog na Vatikanskom saboru 1869-1870 (Die Reden des Bischofs Strossmayer vo Đakovo und Srijem auf dem I. Vatikanum), Zagreb 1929.

${ }^{23}$ I. Petrović, Franjo Raki, otac hrvatske cyrillomethodhiane (Franjo Raki, der Vater der kroatischen Idee von Cyrill und Methodius), [w:] Zbornik Zavoda za povijesne znanosti istraživakog centra JAZU, 9, 1979; Katoliki biskupi Jugoslavije, O svetoj bra i Ćirilu i Metodu (Die katholischen Bischöfe Jugoslawiens über die heiligen Cyrill und Methodius), Đakovo 1963. 
Po przekształceniu Austro-Węgier w monarchię dualistyczną, Węgrzy uznali Chorwatów za jedyny poza nimi naród polityczny i w $1868 \mathrm{r}$. zawarli z nimi umowę podpisaną przez cesarza ${ }^{24}$. Na jej podstawie utworzono Trójjedyne Królestwo Chorwacji, Slawonii i Dalmacji ${ }^{25}$. Najczęściej w skrócie używano nazwy Trojednica. Austriacy i Węgrzy nie byli konsekwentni w przestrzeganiu zapisów umowy. Dalmację Austriacy traktowali jako kraj koronny Cesarstwa Austrii, a obszar Pogranicza Wojskowego dopiero po kilku latach oddali pod bezpośrednią administrację Zagrzebia, nadal utrzymując nad nim kontrolę $e^{26}$.

W punkcie 1 umowy wymieniona była Rijeka i przylegający do niej region oraz 6 komitatów (vermegye, županija) na terenie Chorwacji i Slavonii. Po wydzieleniu Rijeki i podziale przylegającego do niej regionu terytorium Królestwa Chorwacji i Slavonii zostało podzielone na 8 komitatów: Belovár-Körös/Bjelovar-Križevci (Bjelovar), Lika-Kravaba (Gospić), Modrus-Fiume/Modruška Rijeka (Ogulin), Pozsega/Požega (Požega), Szerém/Sremski (Vukovar), Varasd/Varaždin (Varaždin), Verőce/Virovitica (Osijek, Virovitica), Zágráb/Zagreb (Zagrzeb).

Mapa 2. Komitaty (županje) chorwackie w (zaznaczone na zielono)

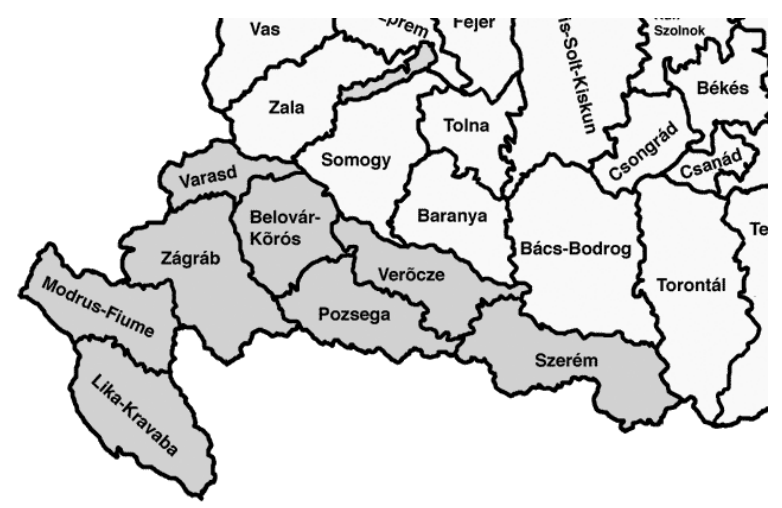

Źródło: http://commons.wikimedia.org/wiki, File: Croatia-Slavonia-Kingdom-of-Hungary.png. Ta grafika została (lub jest niniejszym) opublikowana jako własność publiczna przez jej autora, I. Meowbot, w projekcie angielskim Wikipedia [29.07.2013].

Po długiej i ostrej dyskusji, w której Węgrzy powoływali się na austriacką ustawę z 21 grudnia 1867 r. w sprawie Dalmacji, w umowie z 1868 r. znalazło się bardzo

${ }^{24}$ Wersja węgierska: 1868. évi XXX. törvénycikk a Magyarország, s Horvát-, Szlavon és Dalmátországok közt fenforgott közjogi kérdések kiegyenlítése iránt létrejött egyezmény beczikkelyezéséről, http://www.1000ev.hu/index [28.07.2013], Nyitólap 1849-1018. Croatian-Hungarian Compromise of 1868, Article I of the Croatian Sabor and article XXX of the Hungarian Sabor). Wersja chorw.: Hrvatsko-ugarska nagodba 1868.

25 Chorw.: Trojedna kraljevina Hrvatska, Slavonija i Dalmacija lub Trojjediné království dalmatské, chorvatské a slavonské, węg.: Horvát-, Szlavon- és Dalmátországok, niem.: Dreieinige Königreich Dalmatien, Kroatien und Slawonien).

${ }^{26}$ Pogranicze Wojskowe i Slavonię zamieszkiwali w większości Serbowie. 
zawiłe sformułowanie, uznające Rijekę za „corpus separatum” węgierskiej korony i stwierdzające, że „miasto, port i zatoka w sposób szczególny są spojone z węgierską koroną i stanowią z nią jedno ciało" ${ }^{27}$. Na podstawie zapisu w umowie z $1868 \mathrm{r}$. przyjęto tzw. Riječką krpicę, która spowodowała, że od roku 1870 Rijeka została prawnie przyłączona do Węgier i znalazła się pod wyłączną węgierską władzą. Oznaczało to $\mathrm{w}$ praktyce, że Rijeka - określana również włoską nazwą Fiume - prawnie nie należała do chorwackiej županii Modrus-Fiume/Modruška Rijeka (Ogulin), lecz administracyjnie stanowiła samodzielną jednostkę, podlegającą bezpośrednio Królestwu Węgierskiemu i zarządzaną przez mianowanego w Budapeszcie gubernatora ${ }^{28}$. W 1910 r. ogólna liczba mieszkańców Rijeki wynosiła 49726 osób. Wśród nich było 24212 Włochów, 12926 Chorwatów, 6493 Węgrów i 2135 Niemców ${ }^{29}$.

Umowa z $1868 \mathrm{r}$. nie wspominała o Međimurju ${ }^{30}$, położonym na północnym wschodzie Chorwacji w widłach Mury i Drawy z centrum w Čakovcu z zamkiem rodu Zrinskich. W obydwu powiatach Međimurja, graniczących przez Drawę z chorwackim komitatem Varasd, lecz należących do węgierskiego komitatu Zala ${ }^{31}$, w 1910 r. żyło 90387 osób, w tym 82829 Chorwatów i 5766 (6,3\%) Węgrów, mieszkających głównie w miastach. Čakoviec liczył wówczas 5213 mieszkańców, w tym: 2433 Węgrów, 2404 Chorwatów i 251 Niemców. Prelog miał w 1910 r. 4518 mieszkańców: 3754 Chorwatów i 713 Węgrów ${ }^{32}$.

Liczba Węgrów mieszkających w komitatach na terenie Królestwa Chorwacji i Slawonii, a tym bardziej Dalmacji, była w sumie niewielka. W 1911 r. ludność Królestwa wynosiła 2621954 mieszkańców, wśród których było: 1638354 (62.5\%) Chorwatów, 644955 (24,5\%) Serbów, 133418 Niemców, 105047 Węgrów i 20884 Słowaków. Największy odsetek Niemców i Węgrów mieszkał w Virovitickim i Sremskim komitacie. Aż 73\% wszystkich mieszkańców stanowili katolicy i 24\% prawosławni.

Królestwo Chorwacji, Slavoni i Dalmacji miało również własne siły zbrojne. Zgodnie z paragrafami 7 i 57 węgiersko-chorwackiej umowy z 8 listopada 1868 r.

27 L. Heka, Hrvatsko-ugarska nagodba u zrcalu tiska, Zb. Prav. fak. Sveuč. Rij. (1991) v. 28, br. 2, 931-971 (2007), s. 956-959. 1868. évi XXX. Törvénycikk: 66. \$ Az előbbi szakasz értelmében Horvát-, Szlavon- és Dalmátországok területéhez tartozóknak ismertetnek el: 1. Mindazon terület, mely jelenleg Buccari városával és kerületével együtt Fiume vármegyéhez tartozik, Fiume város és kerülete kivételével, a mely város, kikötö és kerület a magyar koronához csatolt külön testet (separatum sacrae regni coronae adnexum corpus) képez, s a melynek, mint ilyennek, külön autonomiájára s erre vonatkozó törvényhozási és kormányzati viszonyaira nézve, Magyarország országgyülése s Horvát-, Szlavon- és Dalmátországok országgyülése és Fiume városa közt, küldöttségi tárgyalások utján, közös egyetértéssel lesz megállapodás eszközlendö.

28 Povijest Rijeke, ur. D. Klen, Izdavački centar Rijeka, Rijeka 1988.

${ }^{29}$ Magyar Katolikus Lexikon > F > Fiume, http://lexikon.katolikus.hu/F/Fiume.html [29.07.2013].

30 Powierzchnia Međimurja wynosi 729,5 km².

31 Według węgierskiego spisu ludności w 1891 r. całkowita liczba mieszkańców komitatu Zala wynosiła 404699 osób, w tym: 296145 (73,2\%) Węgrów, 79737 (19,7\%) Chorwatów, 21380 (5,2\%) Vendów (Słoweńców głównie w powiecie Alsólendva w Prekmurju po drugiej stronie Mury) i 6355 Niemców.

32 Republika Hrvatska Državni zavod za statistiku (DZS). Naselja i stanovnitvo Republike Hrvatske 1857-2001, http://www.dzs.hr/ [data dostępu???]. 
miały one funkcjonować jako Horvát-szlavon Honvédség, czyli siły zbrojne obrony krajowej w strukturze węgierskiego Honvedu w Królestwie Węgierskim i podlegać jego dowództwu ${ }^{33}$. Na tym tle doszło jednak do ostrych sporów, w których szczególną rolę odegrał hrabia gen. Miroslav Kulmer z Zagrzebia. Jego zdaniem chorwackie siły zbrojne powinny nawiązywać do tradycji bana Josipa Jelačićia z $1848 \mathrm{r}$. i podlegać bezpośrednio cesarzowi. Franciszek Józef I odniósł się przychylnie do aspiracji chorwackich. Siły zbrojne Królestwa Chorwacji, Slavonii przyjęły nazwę Hrvatsko-Slavonsko Domobranstvo ${ }^{34}$.

\section{Znaczenie zwycięskiej ofensywy Frontu Salonickiego w 1918 r.}

Próba realizacji i utrwalenia austriacko-węgierskiej polityki wobec Serbii i Bałkanów została podjęta w I wojnie światowej. Królestwo Serbii było pierwszym państwem, które 28 lipca 1914 r. zostało zaatakowane przez Cesarstwo Austriacko-Węgierskie ${ }^{35}$. Główne uderzenie na Serbię przypuściły 5 i 6 armie austriacko-węgierskie, w skład których wchodziły XIII sformowany i stacjonujący w Chorwacji oraz VIII Korpus zorganizowany w Bośni i Hercegowinie anektowanej przez Austrię w 1908 roku ${ }^{36}$. W pierwszym ataku na Serbię ze Śremu zaatakowała 42 dywizja piechoty chorwackiego Domobranstwa, dowodzona przez gen. Stefana Sarkotićia.

W pierwszym roku wojny armia serbska skutecznie odpierała ataki armii austriacko-węgierskich, odnosząc kilka znaczących zwycięstw. Gdy jednak w 1915 r. do wojny przeciwko Serbii przystapiła Bułgaria, a Niemcy przysłały 11 armię $^{37}$, osamotniona Serbia $z$ trzystutysięczną armią nie była w stanie powstrzymać liczących 800 tys. żołnierzy dobrze zaopatrzonych wrogich armii. W niezwykle ciężkich zimowych warunkach armia serbska wycofała się jedyną możliwą drogą przez Albanię do Adriatyku. Okręty włoskie przewiozły około 119 tys. żołnierzy serbskich na Korfu i inne wyspy greckie.

Jesienią 1915 r. do Salonik w Grecji przybyły dwie brygady: francuska i angielska, które miały pomóc wycofującym się Serbom, było jednak za późno. Wbrew stanowisku rządu angielskiego, który chciał wycofać swoją brygadę, dowództwo armii

${ }^{33}$ A part of the Royal Hungarian Landwehr was the Royal Croatian Landwehr (Kraljevsko hrvatsko domobranstvo), which consisted of 1 infantry division (out of 7 in Honved) and 1 cavalry regiment (out od 10 in Honved).

${ }^{34}$ M. Jareb, Ustaško-domobranski pokret: od nastanku do travnja 1941 Godine, Školska knjiga, 2006; M. Pojić, Ustroj Austrougarske vojske na ozemlju Hrvatske 1868-1914, Arhivski vjesnik, No. 43, Ožujak 2001.

35 А. Митровић, Продор на Балкан. Србија у плановима Аустроугарске и Немачке 1908-1918, Београд 2011; idem, Србија у Првом светском рату, Београд 1987 (wyd. ang.: Serbias' Great War 1914-1918, London 2007); idem, Аустро-Угарска политика и Србија у Првом светском paтy,http:// www.istorijskabiblioteka.com/art:andrej-mitrovic [29.07.2013].

36 T. Nowakowski, Armia Austro-Wegierska 1908-1918, Warszawa 1992; Rest-Ortner-Ilmig, Des Kaisers Rock im 1. Weltkrieg - Uniformierung und Ausrüstung der österreichisch-ungarischen Armee von 1914 bis 1918, Wien 2002; M. Rauchensteiner, Österreich-Ungarn und der Erste Weltkrieg: Bildband, Graz 1998; J. Ch. Allmayer-Beck, E. Lessing, Die K.u.k. Armee. 1848-1918, München 1974.

37 H. Cron, Geschichte des Deutschen Heeres im Weltkriege 1914-1918, Berlin 1937. 
francuskiej zajęło zdecydowane stanowisko, by przyczółek aliancki w Salonikach w Grecji nie tylko utrzymać, ale także rozbudować i maksymalnie wzmocnić.

Był to początek alianckiego frontu na Bałkanach, który nazywany był Frontem Salonickim, a niekiedy również Frontem Macedońskim ${ }^{38}$. Przybywały do Salonik dywizje angielskie i francuskie formowane w Nowej Zelandii, Indiach, Indochinach oraz w Afryce ${ }^{39}$. Dwie brygady utworzyli Rosjanie, 6 dywizji serbskich było sformowanych $\mathrm{z}$ ocalałych żołnierzy armii serbskiej ${ }^{40}$. Przyczółek utworzony przez „ogrodników z Salonik” - jak nieco ironicznie nazywano pierwszych żołnierzy brygady francuskiej i angielskiej - rósł w siłę, powstrzymywał jednostki bułgarskie, niemieckie i austro-węgierskie, utworzył front wzdłuż całej granicy grecko-bułgarskiej, grecko-macedońskiej i grecko-albańskiej ${ }^{41}$. Pozycje obydwu walczących stron ciągnęły się od Morza Egejskiego aż do Adriatyku na długości 350 kilometrów.

Mianowany w połowie 1918 r. nowy Naczelny Dowódca Sił Sprzymierzonych na Bałkanach, francuski marszałek Louis Félix Marie François Franchet d'Espérey, w połowie września 1918 r. na Froncie Salonickim miał do dyspozycji 29 dywizji piechoty, brygadę kawalerii, 2070 dział różnego kalibru. Siły te liczyły w sumie 670 tys. żołnierzy ${ }^{42}$, były wśród nich dwie armie serbskie składające się w z sześciu dywizji piechoty (119 tys. żołnierzy).

Zwycięska ofensywa rozpoczęła się 14 września 1918 r. od przygotowania artyleryjskiego, a następnego dnia zaatakowała piechota i kawaleria. Po dwóch tygodniach walk Bułgaria uznała się za pokonaną i w Salonikach 29 września $1918 \mathrm{r}$. podpisała akt kapitulacji. Wszedł on w życie 30 września. Walczące na prawym skrzydle dywizje angielskie i greckie po pokonaniu armii bułgarskiej wyruszyły na Konstantynopol i 26 października zmusiły do kapitulacji Turcję (the Armistice of Mudros). Dywizje francuskie i serbskie, pokonując opór grupy niemieckiego generała Scholtza, a szczególnie 11 armii niemieckiej, posuwały się na północ, wyzwalając Macedonię, a następnie Serbię. 1 listopada 1918 r. oswobodzono Belgrad. Dywizje serbskie zajęły pozycję nad Dunajem.

Marszałek d'Espérey 3 listopada posłał do naczelnego dowództwa Ententy plan działań dowodzonego przez niego Frontu Salonickiego, wykreślając jego kierunek: Budapeszt, Praga, Wiedeń, Berlin. Propozycja ta w Paryżu wywołała przede wszystkim zakłopotanie.

38 Commandant Desmazes, Cours d'Histoire Militaire, Guerre de 1914-1918, Juillet 1920; J. Ancel, Les travaux et les jours de l'Armée d'Orient, Paris 192; M. Tinayre, "Un Été à Salonique » in Balkans en Feu à l'Aube du XXesiècle, Edition Omnibus 2004.

39 G. Th. Vafopoulos, Dans la Guerre mondiale, [w:] G. Veinstein, Salonique 1850-1918, Paris 2001, s. 259.

40 P. Opačić, Srbija, Solunski front i ujedinjenje, Beograd 1990, Književne novine.

41 A. Vacalopoulos, A History of Thessaloniki, Thessalonique 1972, s. 256.

42 Po zawarciu traktatu brzeskiego 3 marca 1918 r. między Niemcami i Austro-Węgrami a Rosją (już wówczas rządzoną przez bolszewicką Radę Komisarzy Ludowych na czele z Leninem) brygady rosyjskie formalnie nie mogły uczestniczyć w walkach. 
Postawa i sukcesy serbskich dywizji oznaczały wzrost siły i politycznego znaczenia Królestwa Serbii i współpracującego z nim Komitetu Jugosłowiańskiego, zapowiadającego utworzenie Państwa Słoweńców, Chorwatów i Serbów, żyjących w krajach monarchii austro-węgierskiej. Zmobilizowało to do podjęcia działań Włochów, mających przyrzeczone w Układzie Londyńskim tereny i porty należące do Austriaków i Węgrów w Istrii i Dalmacji. Włosi wzmocnieni oddziałami amerykańskimi 23 października rozpoczęli ofensywę znaną pod nazwą „La battaglia di Vittorio Veneto", nagłośnioną następnie jako wielkie zwycięstwo ${ }^{43}$. Początkowo wygrana nie przychodziła Włochom łatwo i bez strat, ale po kilku dniach walki jednostki austro-węgierskie zaczęły masowo poddawać się ${ }^{44}$. Całe oddziały składające się z żołnierzy czeskich przechodziły na stronę włoską i były włączane do Legionu Czechosłowackiego ${ }^{45}$. Austro-Węgry rozpadały się. Nie pomógł nawet manifest cesarza Karola z 16 października, zapowiadający przekształcenie Cesarstwa Austro-Węgierskiego w federację równoprawnych narodów. Było już za późno. W Krakowie, Pradze, Lublanie i Zagrzebiu 28 października narody i kraje słowiańskie w Cesarstwie Austro-Węgierskim ogłosiły utworzenie niepodległych państw. Pomogło to Włochom odnieść sukces. Austriacy woleli złożyć akt kapitulacji na ręce włoskie, co nastąpiło 3 listopada. W imieniu dowództwa armii austro-węgierskiej akt kapitulacji w Villa Giusti koło Padwy podpisał Victor Maria Willibald von Weber Edler Webenau. Poddanie się przyjął gen. Pietro Badoglio, dowódca sił włoskich w północno-wschodnich Włoszech. Przed Włochami otworzyła się wolna droga do Istrii i Dalmacji.

\section{Zajęcie Baranii, Baczki-Bodrog i Banatu przez Serbię}

Czołowe oddziały serbskich i francuskich dywizji w wielu punktach osiągnęły linię Dunaju już w dniach 29-30 października 1918 roku. Przekraczanie linii Dunaju, czyli zajmowanie przedwojennego terytorium Królestwa Węgierskiego, rozpoczęło się 5 listopada ${ }^{46}$.

${ }^{43} \mathrm{~Np}$. Benito Mussolinii w przemówieniu 4 listopada 1930 r.: G. Taretti, Benito Mussolini - Duce del Fascismo, Roma 1937, s. 188. W sposób zdystansowany charakter tej bitwy oceniali natomiast: G. Prezzolini, Vittorio Veneto, Rom 1920, s. 34; L. Tosi, La propaganda italiana allestero nella prima guerra mondiale - Rivendicazioni territoriali e politica delle nazionalità, 1977, Del Bianco Editore [Civiltà del Risorgimento]; D. Ceschin, Gli esuli di Caporetto, Laterza 2006.

${ }^{44} \mathrm{~W}$ orientacyjnym bilansie straty wojsk austro-węgierskich wyniosły: 35000 zabitych, 100000 zaginionych, 300000 wziętych do niewoli. H. Magenschab,Der Krieg der Großväter 1914-1918. Die Vergessenen einer großen Armee, Wien 1988; M. Rauchensteiner, Der Tod des Doppeladlers. Österreich-Ungarn und der Erste Weltkrieg, Styria, Graz, Wien, Köln 1993; P. P. Cervone, Vittorio Veneto. Lultima battaglia, Mailand 1994. D. Stevenson, With our backs to the wall. Victory and defeat in 1918, Cambridge MA 2011.

45 J. F. Triska, Im Krieg am Isonzo. Aus dem Tagebuch eines Frontsoldaten, Klagenfurt 2000.

${ }^{46}$ S. Marković, Dani oslobođenja devedeset godina od prisajedinjenja Vojvodine Kraljevini Srbijii stvaranja Kraljevine Shs (III deo), BUNJEVAČKE n o v i n e, Informativno-političko glasilo, Subotica, novembar 2008, Godina IV, Broj 41, s. 20-21, dostępne również: http://bunjevci.com/novine/pdf/ bunjevacke/2008_41.pdf [29.07.2013]. 
Mapa 3. Barania, Baczka i Banat zajęte przez wojsko Królestwa Serbii 25 listopada 1918 r.

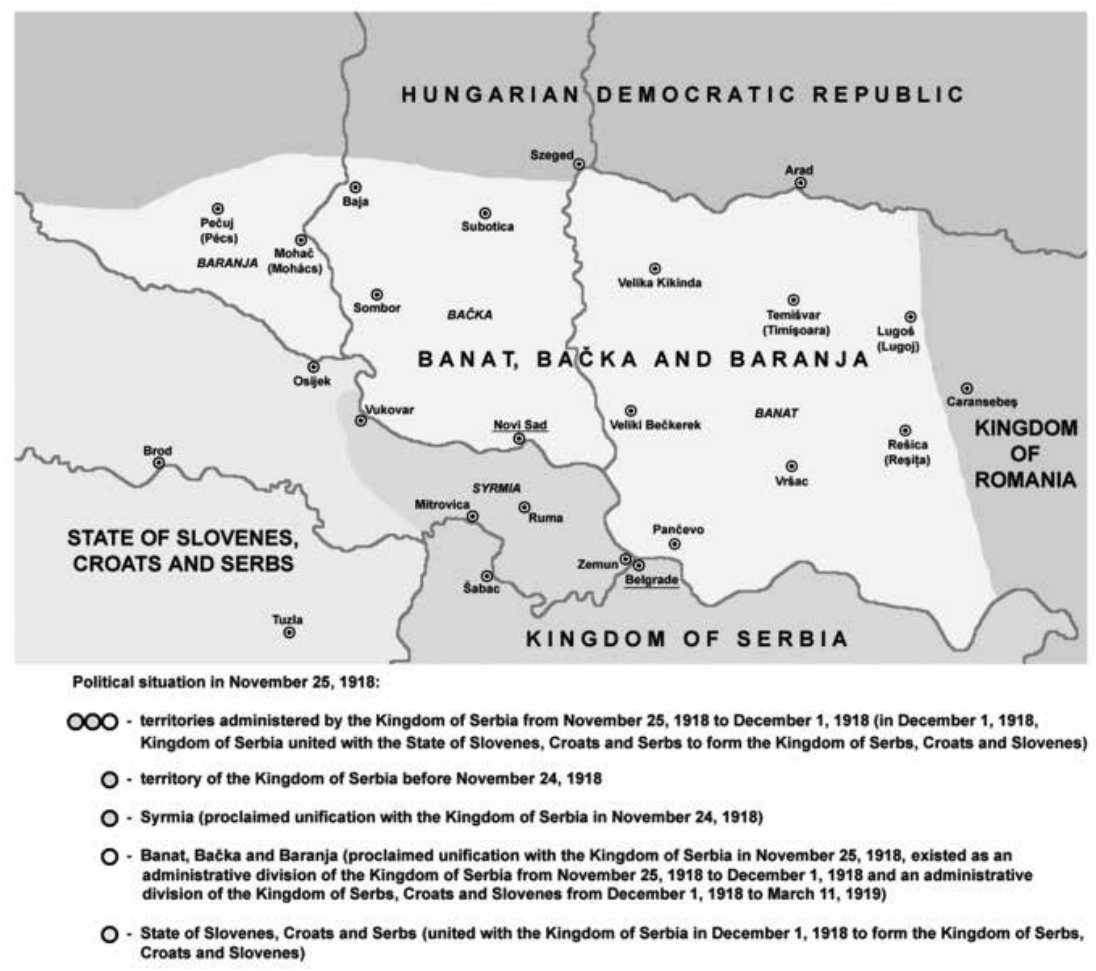

Źródło: This work has been released into the public domain by its author, PANONIAN. This applies worldwide. In some countries this may not be legally possible, http://upload. wikimedia.org/wikipedia/commons/6/60/Banat-backa-baranja [29.07.2013].

Obowiązujący od 4 listopada akt kapitulacji Austro-Węgier wyznaczał linię demarkacyjną, za którą musiały wycofać się oddziały węgierskie. Przekroczenie tej linii na terenie Węgier przez oddziały Ententy było uzasadnione kontynuowaniem pościgu za wycofującymi się na Węgry jednostkami 11 armii niemieckiej, oddziałami niemieckimi ze zgrupowania gen. Friedricha von Scholtza oraz działaniem przeciwko wychodzącej z Rumunii przez Węgry armii niemieckiej marszałka Augusta von Mackensena.

9 listopada oddziały serbskie zajęły Nowy Sad (Újvidék) w komitacie Bács-Bodrog, stolicę Wojvodiny ${ }^{47}, 10$ listopada Vršac w Banacie, 13 listopada Sombor ${ }^{48}$ i Suboticę położoną w północno-wschodniej części komitatu Bács-Bodrog. Tego dnia wojsko serbskie wkroczyło do położonej w widłach Drawy i Dunaju Baranii, zajmując jej południową część w ciągu dwóch dni.

47 D. Njegovan, Prisajedinjenje Srema, Banata, Bačke i Baranje Srbiji 1918. - dokumenti i prilozi, Novi Sad 2001, idem, Prisajedinjenje Vojvodine Srbiji, Novi Sad 2004.

48 R. Šumonja, Spomenica oslobođenja Sombora 1918-1998, Sombor 1998. 
15 listopada zostało zdobyte miasto Senta, 17 - Bečkerek, 18 - Titel i Kikinda. 15 listopada dotarły one do Timisoary, likwidując podjętą przez Otto Rotha próbę utrzymania w Banacie władzy przez Niemców i Węgrów ${ }^{49}$. W tej sytuacji Mihály Károlyi, od 31 października premier nowego rządu węgierskiego, zwrócił się do marszałka d'Espérey z prośbą o spotkanie. Rozpoczęło się ono w nocy z 6 na 7 listopada w Belgradzie, do którego marszałek d’Espérey dotarł ze swojej kwatery głównej w Niszu. Mihály Károlyi przybył na czele 12-osobowej delegacji nowego rządu węgierskiego. Spotkanie rozpoczęło się od odczytania wstępnego oświadczenia przez premiera węgierskiego. Marszałek d'Espérey kilkakrotnie ostro je przerywał. Po raz pierwszy zakłócił oświadczenie Károlyego, gdy usłyszał stwierdzenie, że premier rządu węgierskiego kieruje się troską o dobro wszystkich narodów Królestwa Węgierskiego. Marszałek d’Espérey stanowczo wówczas oświadczył, że Károly ma prawo reprezentować i wypowiadać się jedynie w imieniu Węgrów. Z wyraźną irytacją d’Espérey zwrócił przy tym uwagę na obecność w składzie delegacji rządu węgierskiego osób o pochodzeniu żydowskim. Byli to Oszkár Jaszi ${ }^{50}$, minister spraw zagranicznych, Béla Linder ${ }^{51}$, minister obrony, a także Lajos Hatvany ${ }^{52}$. Po raz drugi d'Espérey zareagował, gdy premier Károly usiłował zasugerować, że Węgry nie ponoszą winy za wybuch wojny i są krajem neutralnym, od 4 listopada bowiem walczą z aliantami już tylko Niemcy ${ }^{53}$. Cała rządowa delegacja węgierska usłyszała wówczas, że reprezentuje kraj pokonany i zobligowany do przestrzegania warunków kapitulacji Austro-Węgier przyjętej w Padwie 3 listopada i obowiązującej od 4 listopada. W ten sposób rozwiane zostały nadzieje rządu Károlyego, że po oderwaniu się od Cesarstwa Austro-Węgierskiego i ogłoszeniu niepodległości, Węgry unikną statusu państwa pokonanego. Uzyskawszy akceptację rządu francuskiego na czele z Georgesem Clemenceau, premierem rządu francuskiego i ministrem obrony, marszałek d’Espérey 9 listopada 1918 r. podyktował przybyłej z Budapesztu węgierskiej delegacji rządowej przebieg linii demarkacyjnej, poza którą miało wycofać się wojsko węgierskie ${ }^{54}$.

49 J. Gyula, Hungarian Foreign Policy 1919-1945, Budapest 1979, s. 14-27.

50 T. Kopyś, op. cit., ss. 192 (rec. R. Zawistowska, [w:] Polityka i Bezpieczeństwo, s. 260-268).

51 Rodzice Jasziego I Lindera (podobnie jak Lajosa Hatvaniego, będącego również w składzie węgierskiej delegacji) wywodzili się z rodzin żydowskich, które poddały się asymilacji. Marszałek d’Espérey wyraził niezadowolenie, że delegacja węgierska nie składała się z samych Węgrów.

${ }^{52}$ Ich rodzice poddali się asymilacji w okresie wzmożonej madziaryzacji.

${ }^{53}$ Po podpisaniu przez Niemcy kapitulacji, Węgrzy pod naciskiem aliantów rozbroili i internowali żołnierzy dywizji niemieckich wycofujących się z Rumunii. Ich dowódca marszałek August von Mackensen, od początku 1917 r., niemiecki wojskowy gubernator okupowanej Rumunii 20 listopada został internowany w Budapeszcie. W marcu 1919 r. na krótko przed przejęciem na Węgrzech władzy przez komunistów został przekazany aliantom. Przebywał jako internowany w Salonikach do listopada 1919 r., po czym został przewieziony do Francji i zwolniony w grudniu 1919 roku. Vide: J. Galántai, Magyarország az első világháborúban, Budapest 2001.

${ }_{54}$ B. Krizman, The Belgrade Armistice of 13 November 1918, „The Slavonic and East European Review", 1970, 48 (110), ss. 67-87. 
Mapa 4. Linie demarkacyjne na Węgrzech po I wojnie światowej

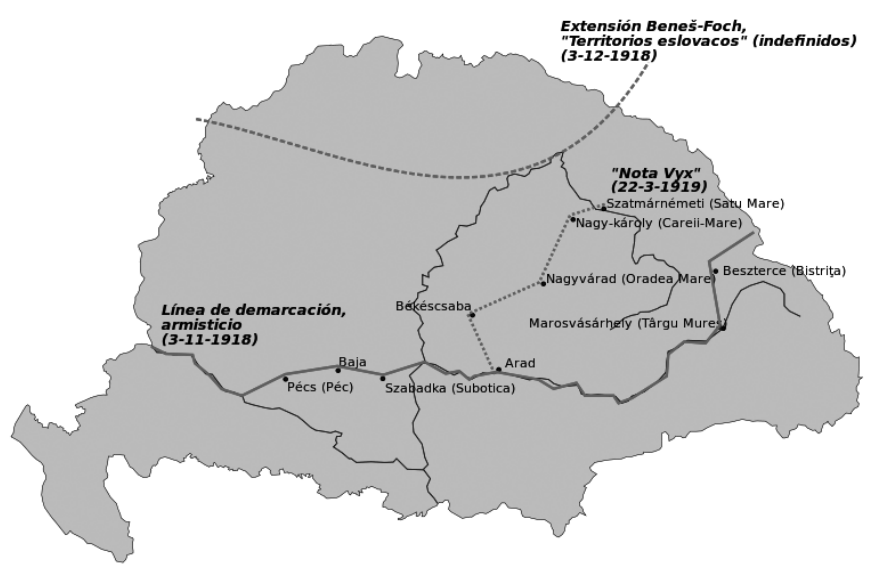

(Ciągła ustalona na podstawie aktu kapitulacji Austro-Węgier z 3 listopada, przekazana Węgrom 9 listopada i zapisana w porozumieniu z 13 listopada 1918 r.)

Źródło: Archivo:ArmisticioDeBelgradoYHungría19181919.svg, Español: Hungría y el armisticio de Belgrado del 3-11-1918, con los sucesivos cambios en Eslovaquia y Transilvania, 1 de julio de 2011, Trabajo popio, Autor: https://es.wikipedia.org/wiki/Armisticio_de_Belgrado_(1918), [29.07.2013].

Porozumienie, zawierające 18 punktów podyktowanych Węgrom, przewidujące zawieszenie broni, prawa zwycięskich wojsk i określające przebieg linii demarkacyjnej między Węgrami a Królestwem Serbii, zostało podpisane w Belgradzie 11 listopada 1918 roku. Podpisali je: Béla Linder w imieniu rządu węgierskiego, vojvoda Živojin Mešić w imieniu Królestwa Serbii i francuski generał Paul Prosper Henrys w imieniu Alianckiego Dowództwa na Bałkanach (Frontu Salonickiego). 13 listopada porozumienie zatwierdził marszałek d'Espérey ${ }^{55}$.

Wkraczające do Baranii, Bački i Banatu wojska serbskie witali radośnie nie tylko Serbowie, ale także zamieszkała tam słowiańska ludność innych narodów, narodowości i grup etnicznych ${ }^{56}$. Szczególną aktywność wykazały grupy etniczne Bunjevców i Šokców ${ }^{57}$. W chorwacko-serbskich sporach identyfikacja narodowa

${ }^{55}$ Capt. C. Falls, Official History, Military Operations: Macedonia, Vol. II: From the Spring of 1917 to the End of the War, London 1935, HMSO; A. Wakefield \& S. Moody, Under the Devil's Eye: Britain's Forgotten Army at Salonika 1915-1918, Stroud 2004.

${ }^{56}$ Wkraczających do Suboticy żołnierzy serbskich powitał w patetycznych słowach Blasko Rajic, lider Bunjevców. Używał słowa Jugosławia, mówiąc o tworzonym wspólnym państwie południowych Słowian.

57 M. Čović, A. Kokić, Bunjevci i Šokci, Hrvatsko književno društvo sv. Jeronima, Zagreb 1939, ss. 39; A. Sekulić, Bački Bunjevci i Šokci, Zagreb 1990, ss. 355; Suboti ka Danica ili Bunjevačko-Šokački 
Bunjevców i Šokców stanowiła ważny problem. Krešimir Bušić z chorwackiego Instytutu Nauk Społecznych w interesującym artykule opublikowanym w 2005 r. podjął próbę wykazania, że Bunjevcy i Šokcy - mieszkający w wielu wsiach i miastach Baranii i Baczki - są Chorwatami, zbijając argumenty serbskie usiłujące udowodnić, że Bunjevcy i Šokcy są Serbami ${ }^{58}$.

25 listopada Zgromadzenie Narodowe Słowian w Nowym Sadzie przyjęło Oświadczenie o oderwaniu się od Węgier południowych hrabstw i przyłączeniu się do Królestwa Serbii. W Zgromadzeniu wzięło udział 757 delegatów: 578 Serbów, 84 Bunjevców, 62 Słowaków, 21 Rusinów, 3 Šokców, 2 Chorwatów, 6 Niemców i 1 Węgier ${ }^{59}$.

Decyzję o zasadniczym znaczeniu dla wielowiekowej podległości Chorwacji Węgrom i Austrii podjął parlament (sabor) Królestwa Chorwacji i Slavonii 29 października 1918 roku. W przyjętej deklaracji sabor uznał, że władza Habsburgów w Chorwacji dobiegła końca, a chorwacko-węgierska umowa z 1868 r. straciła ważność. Odrzucona została propozycja przyłączenia się do Węgierskiej Republiki Demokratycznej; na zasadach federacji chorwacki sabor przeniósł władzę na Radę Narodową powstającego niezależnego Państwa Słoweńców, Chorwatów i Serbów. Opowiedział się też za oderwaniem od Węgier Međimurja i przyłączeniem go do Państwa SHS ${ }^{60}$. Przyjęcie takich uchwał ułatwił polityczny skład saboru. W ostatnich wyborach przeprowadzonych 16 i 17 grudnia 1913 r. zwyciężyła Hrvatsko-Srpska Koalicja, uzyskując w 88 -osobowym saborze 48 przedstawicieli ${ }^{61} .30$ października węgierski parlament w Budapeszcie przyjął uchwałę o ustaniu wszystkich dotychczasowych państwowo-prawnych więzi między oboma krajami, co oznaczało przyznanie Chorwacji niepodległości. Po upływie miesiąca od wyzwolenia Belgradu, 1 grudnia 1918 r., Państwo SHS utworzone 28 października przez słowiańskich poddanych austriackich (Słoweńcy, Chorwaci i Serbowie - głównie ze Slavonii) dobrowolnie zgłosiło akces do Królestwa Serbii. Powstałe w ten sposób państwo przyjęło nazwę Królestwo Serbów, Chorwatów i Słoweńców ${ }^{62}$.

\section{Oderwanie od Węgier i przyłączenie do Chorwacji Međimurja}

Spektakularny charakter miała akcja oderwania od Węgier i połączenia z Chorwacją Međimurja ze stolicą w Čakovcu ${ }^{63}$. Međimurje określane przez Węgrów nazwą

kalendar, Subotica 1937-1941; H. Baerlein, The Birth of Yugoslavia, Vol. I, London 1922 (rozdz.: BUNJEVCI, ŠOKCI AND KRAŠOVANI, s. 87-91).

${ }^{58}$ K. Bušić, Odjeci uspostave Banovine Hrvatske u Hrvatsko-Bunjevačkoj javnosti, Druš. Istraž. Zagreb GOD. 14 (2005), BR. 4-5 (78-79), s. 719-741.

59 S. Marković, Dani oslobođenja (treći deo), „Bunjevačke novine”, br. 41, (novembar 2008), s. 21.

${ }^{60}$ Ibidem.

61 B. Dubravica, Parliamentarni izbori u Hrvatskoj i Velikoj Gorici (1848-1938), Velika Gorica 2004, s. 189-190 (Izbori za Hrvatsko-slavonsko-dalmatinski sabor održani su 16 i 17 prosinca 1913).

${ }^{62}$ W skrócie już wówczas używana było określenie Jugosławia, chociaż dopiero w 1929 r. oficjalnie Królestwo SHS zmieniło nazwę na Królestwo Jugosławii.

${ }^{63}$ I. Novak, Medimurje 1818, [w:] Prijelomne godine. Međimurje 1848. 1918, Uz 150. I 80 obletnicu priklučenja Međimurja Hrvatskoj, Muzej Međimurja Čakovec, Čakovec, prosinac 1998. W Čakovcu 
Muraköz - podobnie jak powiat Alsólendva járás, stanowiący część słoweńskiego Prekmurja - należało przed I wojną światową do węgierskiego komitatu Zala. Po raz pierwszy Međimurje zostało połączone z komitatem Zala przez Juraja Zrińskiego pana na Čakovcu w 1593 r. Juraj Zriński, syn bohatera Mikołaja spod Szigetu, objął wówczas stanowisko župana komitatu Zala i prawnie przeprowadził odłączenie Čakovca od chorwackiego komitatu Varasd i połączenie z kierowanym przez siebie węgierskim komitatem Zala. W następnych wiekach właściciele zamku w Čakovcu zmieniali się, ale Međimurje pozostawało „w zastawie” węgierskim aż do 1848 roku. Wówczas zostało oderwane od Węgier przez bana Jelačića. Po kilkunastu latach wróciło do komitatu Zala (na początku 1861 r.). Međimurje nazywane przez Węgrów Muraköz dzieliło się na dwa powiaty: Csáktornya (chorw. Čakovec) járás i Perlak (chorw. Prelog) járás. Od słoweńskiego Prekmurja oddzielała je rzeka Mura, a od chorwackiego komitatu Varasd (znany w Polsce pod chorwacką nazwą Varaždin) Drawa. W decyzji przekazanej Węgrom 9 listopada w Belgradzie i zapisanej w układzie z 11 listopada linia demarkacyjna biegła środkiem rzeki Drawy, pozostawiając Međimurje po węgierskiej stronie w komitacie Zala. W listopadzie $1918 \mathrm{r}$. we wszystkich miastach, miasteczkach i wsiach krajów byłych Austro-Węgier niebezpiecznym elementem byli zdemobilizowani, wygłodniali żołnierze, którzy po zakończeniu wojny wracali do swoich najczęściej wynędzniałych, niemających z czego żyć rodzin ${ }^{64}$. Nasilały się rabunki, rozboje, kradzieże, rosły niepokoje społeczne. Wśród wracających do Međimurja byli żołnierze zwolnieni z armii austro-węgierskiej i domobraństwa. Były między nimi różnice, ale łączyło ich przekonanie, że Međimurje powinno być niepodległe i zjednoczone z Chorwacją.

Bosnjak Gèzo župan komitatu Zala w powiatach zamieszkałych przez Słoweńców i Chorwatów nakazał rozplakatowanie zarządzenia, w którym za udział w buntach groził sądami doraźnymi i karą śmierci. Węgierski badacz András Siklós na podstawie dokumentów węgierskich podał 134 ofiary rozruchów w Međumurju ${ }^{65}$. Vladimir Kalšan w swoim opracowaniu przytoczył liczby ustalone przez chorwackich badaczy: 53 ofiary represji (međimurskich mučenika), podane przez Đuro Vilovića w „Jutarnjem listu” (29 rujna 1929), 61 ofiar szacowanych przez dr. Vinko Žganeca ${ }^{66}$ i 110 ofiar wymienionych w książce Vladimira Kapuna ${ }^{67}$. Według przekonania Kalšana pełną liczbę można podnieść do 160 ofiar $^{68}$. W miarę jak policja,

znajduje się zamek Zrinskih, jednego z najsłynniejszych obok Frankepanów rodów chorwackich. Helena Zrińska, córka straconego przez Austriaków Piotra Zrinskiego, była żoną Franciszka I Rakocziego, a po jego śmierci Imre Tökelego, matką Franciszka II Rakocziego - wielkich przywódców powstań węgierskich przeciwko Habsburgom.

${ }^{64} \mathrm{~W}$ miastach środkowej Małopolski w listopadzie 1918 r. atakowane były najczęściej sklepy żydowskie.

65 A. Siklós, Magyarország 1918-1919 - Események, képek, dokumentumok, Budapest 1978, Kossuth Könyvkiadó/Magyar Helikon 1978, s. 127-128.

${ }^{66}$ Međimurski kalendar, 1928 i Hrvati u borbamaza oslobodenje sjeviernih krajeva Jugoslavije: Međimurja, Prekomurja, Koruške i Štajerske, Zagreb 1940.

67 V. Kapun, Medimurje 1918, Čakovec 1982.

68 V. Kalšan, Međimurje 1918, [w:] Prijelomne godine. Međimurje 1848. 1918, s. 17. 
wojsko i władze węgierskie stosowały coraz drastyczniejsze formy stłumienia niepokojów i rozruchów, wśród chorwackiej ludności Međimurja nasilało się przekonanie o konieczności jak najszybszego oderwania się od Węgier i przyłączenia do Państwa SHS.

Coraz liczniejsi uciekinierzy przybywali do Varaždinu, prosząc o podjęcie działań, by Međimurje zostało przyłączone do niepodległej Chorwacji w ramach Państwa $\mathrm{SHS}^{69}$. Pierwsi uciekinierzy z Međimurje $\mathrm{z}$ informacjami o węgierskich represjach pojawili się w Varaždinie 8 listopada 1918 roku. Pod wpływem tych sygnałów już 13 listopada podjęto spontaniczną pierwszą próbę odebrania Węgrom Međimurja. Zakończyła się ona niepowodzeniem. Przeprowadziło ją 300 ochotników pochodzących głównie z Međimurja, którzy uderzyli w trzech kolumnach, ale ponieśli dotkliwą porażkę. 14 listopada rano do Čakovca z Nagykaniszi przybyły pociągi $\mathrm{z}$ regularnym wojskiem węgierskim, które pokonało atakujących ${ }^{70}$. W Varaždinie zrozumiano, że akcja odebrania Węgrom Međimurja i przyłączenia do Chorwacji musi być podjęta ze znacznie większymi siłami. W pomoc dla Međimurja od początku szczególnie zaangażowali się dr Pere Magdić, naczelnik miasta Varaždin, i dr Hinko Krizman, przewodniczący Rady Narodowej w Varaždinie. Wspierali oni dr. Ivana Novaka reprezentującego Međimurje w Radzie Narodowej Państwa SHS.

Za pośrednictwem Svetozara Pribićevića, wiceprzewodniczącego RN Państwa SHS, serbskiego polityka z Chorwacji, podjęte zostały zabiegi dyplomatyczne. Zakończyły się one niepowodzeniem. Dowództwo armii serbskiej i dowództwo alianckie oświadczyły, że wiążą ich zapisy rozejmowe ustalające linię demarkacyjną na Drawie, a kwestia przynależności państwowej chorwackiego Međimurja jest wewnętrzną sprawą Chorwatów. Svetozar Pribićević podpowiedział, że układ ten nie wiąże chorwackich jednostek demobilizowanej armii austro-węgierskiej i domobraństwa. Pierwszymi inicjatorami przeprowadzenia takiej akcji była grupa oficerów z 25 i 26 pułku domobrany na czele ze Slavko Kvaternikem - zdemobilizowanym podpułkownikiem armii austro-węgierskiej. W Varaždinie zaczęły skupiać się nierozformowane jeszcze oddziały armii austriacko-węgierskiej, a wśród nich nawet bateria artylerii polowej oraz artylerii ciężkiej z rozformowywanego pułku artylerii XIII Korpusu. Nadciągały również bataliony domobraństwa, które również jeszcze nie poddały się rozbrojeniu i rozformowaniu. Decydujący udział oddziałów domobraństwa w akcji przyłączenia do Chorwacji Međimurja miał duży wpływ na spowolnienie i złagodzenie procesu jego rozformowywania i rozbrojenia.

W Varaždinie w ramach struktury Państwa SHS została powołana Rada Narodowa Međimurja na czele $z$ dr. Ivanem Novakiem. Przez cały czas gromadzenia w Varaždinie możliwie największych sił wojskowych prowadzono rozmowy z dowództwem węgierskim i władzami węgierskimi w Čakovcu. Oficerom z armii austro-węgierskiej i chor-

${ }^{69}$ Hrvati u borbama za oslobođenje sjevernih krajeva Jugoslavije: Međumurja, Prekomurja, Koruške i ̌́tajerske, sabrao, uredio i za tisak pripremio Petar Jelavić: Udruženje ratnih dobrovoljaca Međumurja, Prekomurja, Koruške i Štajerske, Zagreb 1940.

70 Dr B. Krizman, Oslobodenje Medimurja 1918, Zagreb, Narodni list 28, 29 i 30 studenoga 1954. 
wackiego domobraństwa stanowiącego formalnie część węgierskiego Honvedu łatwiej było znaleźć wspólny język z przedstawicielami strony węgierskiej. Akcja zajęcia Međimurja została szczegółowo zaplanowana na 24 grudnia 1918 roku. Podpułkownikowi Dragutinowi Perko udało się jednak przekonać Węgrów i nie doszło do walki. Węgierski major Györy w Čakovcu podpisał protokół przekazania Međimurja dowódcy sił chorwackich ${ }^{71}$. W dzień Bożego Narodzenia przez Čakovec przedefilowały oddziały chorwackie na czele z podpułkownikiem Slavko Kvarernikiem. 26 grudnia przekazał on dowództwo podpułkownikowi Dragutinowi Perko, który został pierwszym dowódcą wojskowym Međimurja po przyłączeniu do Chorwacji. Już następnego dnia 27 grudnia 1918 r. dr Ivan Nowak zorganizował w Čakovcu pierwsze zebranie z Radą Narodową Međimurja. Przyjęto na nim uchwałę, że wszyscy urzędnicy, którzy znali język chorwacki, nie brali udziału w madziaryzacji ani nie uczestniczyli w jakikolwiek sposób w prześladowaniu i terroryzowaniu ludności chorwackiej, mogą pozostać na swoich stanowiskach pracy. Tę samą zasadę zastosowano wobec nauczycieli. Dr Ivan Nowak oświadczył przy tym: „Musimy mieć serca i póki są im zawierzyć"72. Na pierwszym zebraniu Rady Narodowej powołano Komitet ds. Oświaty. Jego pierwszym zadaniem było przeprowadzenie rozmów z nauczycielami. $\mathrm{Ci}$, którzy nie chcieli dalej pracować lub nie spełniali kryteriów, otrzymali niezbędne dokumenty, zaopatrzenie na drogę i bilet kolejowy do Nagykaniszi.

9 stycznia 1919 r. na Placu Franciszkańskim przed Kościołem św. Nikole w Čakovcu odbyła się wielka uroczystość z udziałem około 10 tys. uczestników. Powołano na niej Narodową Skupštinę Međimurja, która uchwaliła Rezolucję o Odłączeniu się od Państwa Węgierskiego, wyrażającą wolę przyłączenia się do Królestwa Serbów, Chorwatów i Słoweńców ${ }^{73}$. Ostateczna decyzja o odłączeniu Međimurja od węgierskiego komitatu Zala i przyłączeniu do Chorwacji została zapisana w traktacie w Trianon 4 czerwca 1920 roku $^{74}$.

Dla uczczenia Rezolucji Narodowej Skupštiny Međimurja 9 stycznia 1919 r. uznano za oficjalny dzień powrotu Međimurja do Chorwacji. Sabor niepodległej Chorwacji w 2005 r. przyjął w tej sprawie specjalną ustawę ${ }^{75}$.

${ }^{71}$ O Međimurju: Povijesna kronologija, http://www.tzm.hr: 24. prosinca 1918, Hrvatske postrojbe predvođene potpukovnikom Perkom ulaze u Čakovec, nakon što je mađarski major Györy potpisao predaju, Međimurje priključeno Hrvatskoj.

${ }_{72}$ (Moramo imati srca i za one koji su bili zavedeni), V. Kalšan, op. cit., s. 23.

73 (...) Hrvati iż cielog Medimurja, pred celim svietom otvoreno, odlučno jednodušno i samosviesno izjavljuju: Za uvek se odcjepljujemo od maĐarske države, kojoj smo do sada pripadali samo pod utjecajem sile i protiv svoje volje(...). Knjižnica i čitanica Čakovec. Dr Ivan Novak (1884-1934) nacjonalni preporoditelj i osloboditelj Međimurja. Katalog Izložbe Dokumenata i Ostavštine dr Ivana Novaka u Knjižnici i čitanici Čakovec. Uz 80 obljetnicu oslobođenja Međimurja i priključenja Hrvatskoj 21 XII 1918, Čakovec 1998, s. 2. Međimurske novine, 26 sječnja 1919. Dokumentacje Povjesnog oddjela Muzeja Međimurja v Čakovcu.

${ }^{74}$ Zala vármegye feltámadása Trianon után. Zalai fejek. Bp. 1930.

75 Chorwacki sabor 23 rujna 2005 r. przyjął Zakon o dopunama zakona o blagdanima, spomendanima i neradnim danima u Republici Hrvatskoj, uznający m.in. 9. siječnja - Dan donošenja Rezolucije o odcjepljenju Međimurja od mađarske države, Klasa: 960-01/05-01/02 Zagreb, 23. rujna 2005, „Narodne novine”. 


\section{Sprawa granic węgiersko-jugosłowiańskich na Konferencji Pokojowej w Wersalu. Traktat w Trianon 4 czerwca 1920 roku.}

Królestwu SHS na Konferencji Pokojowej w Paryżu przyznano formalnie trzy miejsca, ale zostało na nie wyznaczonych czterech uprawomocnionych delegatów. Byli to Nikola Pašić, zwolennik centralizmu, unitaryzmu i idei Wielkiej Serbii, Ante Trumbić, zwolennik federalizmu, Milenko Vesnić, serbski dyplomata i minister, a także Ivan Žolger ${ }^{76}$, słoweński prawnik mianowany na członka delegacji na skutek nalegań Antona Korošca, pierwszego wicepremiera rządu. Nikola Pašić 3 marca 1919 r. złożył w imieniu delegacji jugosłowiańskiej Memorandum, które zawierało żądania terytorialne Królestwa SHS w Nizinie Panońskiej z Međimurjem i propozycję utworzenia „„łowiańskiego korytarza” od Jugosławii do Czechosłowacji, ciągnącego się między Austrią i Węgrami (Gradiščanska, Burgenland) ${ }^{77}$. W Memorandum znalazła się również propozycja oderwania od Węgier Prekmurja i przyłączenia go do Słowenii w granicach Królestwa HSS $^{78}$.

Podczas konferencji w Paryżu 13 czerwca 1919 r. podpisano umowę jugosłowiańsko-rumuńską, na podstawie której północno-wschodnią większą część Banatu Serbia odstąpiła Rumunii. Rada Ambasadorów kontynuująca prace Konferencji Pokojowej w Paryżu odrzuciła złożoną 16 kwietnia 1920 r. prośbę etnicznych Niemców z Banatu i Baczki zawierającą wniosek o utworzenie Republiki Banatu i Baczki.

Traktat podpisany w Trianon przywrócił skrawek Banatu Węgrom (0,3 tys. $\mathrm{km}^{2}$ ). 18,7 tys. $\mathrm{km}^{2}$ znalazło się w granicach Rumunii, a 9 tys. $\mathrm{km}^{2} \mathrm{w}$ Królestwie Serbii-Chorwacji-Słowenii.

Spis powszechny przeprowadzony 31 stycznia $1921 \mathrm{r}$. wykazał, że przyłączona do Królestwa SHS część Banatu miała 9776 km² i 582571 mieszkańców ${ }^{79}$ (w tym 3940 wojskowych), w tym: około 240000 Serbów, 2139 Słoweńców, 2081 Czechów, 15544 Słowaków, 6 Rusinów, 2277 Bułgarów, 70 Polaków, 2369 Rosjan, 102104 Węgrów, 138292 Niemców, 4690 Żydów, 375 Albańczyków, 91 Turków, 72305 Rumunów. Wśród mieszkańców serbskiej części Banatu było 310846 prawosławnych, 225 000 katolików, 1649 greko-katolików, 39210 ewangelików, 697 muzułmanów, 69 wyznawców innych religii i 590 niewierzących.

W 1924 r. nastąpiła wymiany kilku miejscowości między Królestwem SHS i Rumunią. Za oddane miasto Modoš ${ }^{80}$ (od tego czasu miastu nadano nazwę Jaša

\footnotetext{
${ }^{76}$ Był włączany do udziału w pracach konferencji tylko podczas omawiania kwestii związanych ze Słowenią.

77 А. Митровић, Југославија на конференцији мира 1919-1920; idem, Разграничавање Југославије са Мађарском и Румунијом 1919-1920. Прилог проучавању југословенске политике на конференцији мира у Паризу (1975).

78 A. Mitrović, Razgraničenje Jugoslavije sa Madžarskom i Romunijom 1919-1920, Novi Sad 1975, s. 72.

79 Попис становништва, домаћинства и станова у 2002, Становништво - књига 1: национална или етничка припадност - подаци по насељима, Република Србија, Републички завод за статистику, Београд, фебруар 2003.

${ }^{80}$ Bezpośrednio po przyłączeniu do Serbii miastu nadano nazwę Jaša Tomić.
} 
Tomić) i kilka innych osiedli Rumunia otrzymała miasto Jimboli i kilka mniejszych miejscowości.

Opracowanie i podpisanie traktatu pokojowego z Węgrami opóźniło się, ponieważ zebrani w Paryżu na konferencję przedstawiciele zwycięskich państw alianckich nie mieli węgierskiego partnera do rozmów ${ }^{81} .19$ marca 1919 r. wezwanie w tej sprawie otrzymał Mihály Károlyi, a za kilka dni powstała Węgierska Republika Rad, władzę przejęli komuniści, a zwycięskie państwa Ententy musiały skupić uwagę na organizowaniu interwencji zbrojnej, by zlikwidować tę próbę i nie dopuścić do połączenia komunistycznego ośrodka władzy na Węgrzech z rosyjskimi leninowskimi bolszewikami. Do pertraktacji został wezwany rząd, który - po stłumieniu władzy komunistów na Węgrzech - powołał Miklós Horthy de Nagybánya. Delegacji węgierskiej podyktowano to, co było już ustalone według zasad zastosowanych w poprzednich traktatach $^{82}$. Traktat Trianoński określanie granicy węgiersko-chorwackiej i węgiersko-serbskiej rozpoczynał od Međimurja ${ }^{83}$. Granica węgiersko-jugosłowiańska (na odcinku z Chorwacją) biegła od granicy ze Słowenią na południowy wschód środkiem rzeki Drawy, opuszczając ją w miejscowości Legrad, około $30 \mathrm{~km}$ od granicy ze

81 A. Sándor, Trianon jogszerüsége, A szerzö magánkiadása, Budapest 2003.

82 K. Salamon, op. cit., s. 13.

83 Treaty of Peace Between The Allied and Associated Powers and Hungary And Protocol and Declaration, Signed at Trianon June 4, 1920:PART II. FRONTIERS OF HUNGARY. ARTICLE 27. 2 With the Serb-Croat-Slovene State:... then to its junction with the old boundary between Hungary and Croatia-Slavonia, about I 1/2 kilometres above the Gyekenyes-Koproncza railway bridge, the course of the Drau (Drave) downstream; thence south-eastwards to a point to be chosen about 9 kilometres east of Miholjacdolnji, the old administrative boundary between Hungary and Croatia-Slavonia, modified, however, so as to leave the Gyekenyes-Barcs railway, together with the station of Gola, entirely in Hungarian territory; thence in an easterly direction to point 93 about 3 kilometres south-west of Baranyavar, a line to be fixed on the ground passing north of Torjancz, Locs and Benge and south of Kassad, Beremend with its railway station and Illocska; thence in a north-easterly direction to a point to be chosen in the course of the Danube about 8 kilometres north of point 169 (Kiskoszeg), a line to be fixed on the ground passing to the west of Baranyavar, Foherczeglak (leaving to the Serb-Croat-Slovene State the railway joining these two places at the junction immediately to the north of Baranyavar) and Dalyok, and to the east of Ivan-Darda, Sarok, Udvar and Izabellafold (with its railway); thence east-north-eastwards to a point in the course of the Kigyos about 3 kilometres east-south-east of Bacsmadaras Station, a line to be fixed on the ground passing between Herczegszanto and Bereg, and then approximately following the course of the Ekigyos, but curving to the north of Rigyicza; thence east-north-eastwards to a point to be selected on the backwater of the Tisza (Theiss) about 5 1/2 kilometres east-north-east of Horgos Station, a line to be fixed on the ground passing south of Kun-Baja, cutting the Szabadka-Bacsalmas railway about 1 1/2 kilometres east of Csikeria Station, cutting the Szabadka-Kiskunhalas railway about 3 kilometres south of Kelebia Station, and passing north of Horgos and its station, and south of Roszkeszentmihalytelek; thence in a south-easterly direction to the Tisza, the median line of the backwater; thence to a point to be selected about 5 kilometres upstream the course of the Tisza; thence in a general easterly direction to a point to be selected on the ground about 4 kilometres south-west of Kiszombor Station, approximztely east-south-east of point 84 and south-south-west of point 83 , this point being the point common to the three frontiers of Roumania, Hungary, and the Serb-Croat-Slovene Statea line to be fixed on the ground passing between Gyala and Oszentivan and between Obeb and Kubekhaza. 
Słowenią. Na podstawie traktatu w Trianon Baranja północna ze stolicą w Pecs i miastami Komló, Mohacs, Szigevár, Harkány pozostała w granicach Węgier ${ }^{84}$, natomiast część południową oddano Królestwu SHS ${ }^{85}$. Z wykonaniem tej decyzji były związane pewne komplikacje. Cała Baranja była wówczas pod kontrolą wojsk Państwa SHS. Po ich wycofaniu słowiańska ludność Baczka i Baranja pozostawionej w granicach Węgier 14 sierpnia 1921 r. ogłosiła powstanie państwa pod nazwą Republika Baranya-Baczka. Istniała ona jednak tylko 11 dni. W okresie od 21 do 25 sierpnia $1921 \mathrm{r}$. węgierskie oddziały wojskowe zajęły przyznane Węgrom w traktacie Trianońskim północne części Baczki i Baranji, po czym podzielono je zgodnie z traktatem w Trianon.

W tym samym czasie, gdy pokonanym Węgrom Chorwaci odebrali Međimurje, nie byli w stanie zająć Dalmacji i Istrii, po które wystąpiły zwycięskie Włochy ${ }^{86}$. Po bitwie pod Vittorio Veneto Włosi bez jakichkolwiek przeszkód wkroczyli do Istrii i północnej Dalmacji. Były to tereny przyrzeczone Włochom przez Ententę w porozumieniu londyńskim z 1915 roku. Na konferencji w Paryżu Włosi chcieli wykorzystać obecność Chorwatów i Słoweńców w składzie delegacji SHS, stwierdzając, że nie będą pertraktować z pokonanymi wrogami i iść im na ustępstwa. Wygórowane żądania Włochów wyhamował nieco prezydent USA Woodrow Wilson, doprowadzając nawet do anulowania Traktatu Londyńskiego z 26 kwietnia 1915 roku $^{87}$. Porty Zadar, Rijeka (Fiume) i cała Istria pozostały w rękach włoskich. 12 września 1919 r. Rijekę zajął oddział ochotników włoskich na czele z Gabriele D’Annunzio. Podczas konferencji w Rapallo w 1922 r. pod naciskiem Francji i Wielkiej Brytanii rządy Królestwa SHS i Włoch wyraziły zgodę na podpisanie porozumienia przewidującego, że Fiume (Rijeka) stanie się osobnym państwem pod opieką Ligi Narodów. Włosi całkowicie zlekceważyli to porozumienie i już 3 marca 1922 r. podporządkowali miasto i port wyłącznie swojej władzy, wprowadzając tam swoje oddziały wojskowe, Królestwo SHS poczuło się zmuszone do uznania aneksji i w zaistniałej sytuacji podpisało z Włochami pakt o przyjaźni ${ }^{88}$.

${ }^{84}$ W 2001 r. ludność węgierskiej Baranyi liczyła 407448 mieszkańców, z czego proporcje narodowościowe przedstawiały się następująco: Węgrzy = 375611 (92,19\%), Niemcy = 22720 (5,58\%), Romowie $=10623$ (2,61\%), Chorwaci $=7294(1,79 \%)$.

${ }^{85}$ W 2001 r. ludność chorwackiej Baranji liczyła 42663 mieszkańców, z czego proporcje narodowościowe przedstawiały się następująco: Chorwaci $=23693$ (55,57\%), Serbowie - 8592 (20,15\%), Węgrzy - 7114 (16,69\%). W większości miejscowości przeważała ludność chorwacka, jedynie w gminie Jagodnjak (2537mieszkańców) - ludność serbska, a w Kneževi Vinogradi (5186 mieszkańców) - węgierska.

${ }^{86}$ Pakt Londyński zawarty 26 kwietnia 1915 r. między państwami Ententy a Włochami przyznawał im Istrię kosztem Austrii i Węgier. 23 maja 1915 r. Włochy wypowiedziały wojnę Austro-Węgrom i zaatakowały na froncie ciągnącym się od Adriatyku na zachód od Triestu wzdłuż całej granicy. Szczególnie ciężkie bitwy toczyły się o dolinę Isonzo i Gorycję. Drogę przez przełęcz Vršič za Kranjską Gorą w masywie Triglava w Alpach Julijskich budowało i utrzymywało 15 tys. jeńców rosyjskich. Śmiertelność wśród nich była bardzo wysoka. Jedna z lawin zasypała jednorazowa prawdopodobnie 600 Rosjan.

87 American Society of International Law, Vol. I, Oxford University Press 1921, s. 253; R. S. Baker, Woodrow Wilson and World Settlement, Vol. I, Doubleday 1923, s. 52-55.

${ }^{88}$ B. Petranović, M. Zečević, Jugoslavija 1918-1984 - zbirka dokumenata, Beograd 1988. 
Tabela 1. Liczby i odsetki ludności węgierskiej we wchodzących w skład Królestwa Węgierskiego Wojwodiny I Chorwacji (1880-1991)

\begin{tabular}{|l|l|l|l|l|l|l|}
\hline & \multicolumn{2}{|c|}{ VOJVODINA } & \multicolumn{3}{c|}{ CROATIA } & \multicolumn{2}{l|}{} \\
\hline Year & \multicolumn{2}{|c|}{ Hungarians } & \multicolumn{2}{c|}{ Hungarians total } & \multicolumn{2}{l|}{ Hungarians in Baranya } \\
\hline & number & $\%$ & number & $\%$ & number & $\%$ \\
\hline 1880 & 265,287 & 22.6 & 49,560 & 1.9 & 14,740 & 32.9 \\
\hline 1910 & 425,672 & 28.1 & 119,874 & 3.5 & 20,313 & 40.0 \\
\hline 1921 & 363,450 & 23.8 & 76,346 & 2.3 & 16,638 & 33.8 \\
\hline 1931 & 376,176 & 23.2 & 66,040 & 1.7 & 15,717 & 30.2 \\
\hline 1941 & 465,920 & 28.5 & 64,431 &.. & 18,585 & 36.4 \\
\hline 1948 & 428,554 & 26.1 & 51,399 & 1.4 & 16,945 & 31.7 \\
\hline 1953 & 435,179 & 25.6 & 47,711 & 1.2 & 16,012 & 31.5 \\
\hline 1961 & 442,560 & 23.8 & 42,347 & 1.0 & 15,303 & 27.3 \\
\hline 1971 & 423,866 & 21.7 & 35,488 & 0.8 & 13,473 & 23.9 \\
\hline 1981 & 385,356 & 18.9 & 25,439 & 0.5 & 9,920 & 18.6 \\
\hline 1991 & 339,491 & 16.9 & 22,355 & 0.5 & 8,956 & 16.5 \\
\hline
\end{tabular}

Źródło: Change in the number and percentage of the Hungarians in Vojvodina, Croatia and Slovenia (1880-1991), Karoly Kocsis and Eszter Kocsis-Hodosi, Hungarian Minorities in the Carpathian Basin. Sources: 1880, 1910: Hungarian census data (mother/native tongue), 1921, 1931: Yugoslav census data (mother/native tongue), 1941: Hungarian census data in Bácska/ Baèka, Baranya and Transmura Region (mother/native tongue), Croatian data in Croatia (mother/native tongue), estimation of K. Kocsis for Banat and Szerém/Srem, 1948-1991: Yugoslav census data (ethnicity).

Remarks: All data were calculated for the present territory of the given regions (except for Croatia in 1880 and 1910 excluding Dalmatia and Istria, in 1921, 1931, 1941 excluding Istria). Baranya - Commune of Pélmonostor/Beli Manastir.

\section{Zakończenie}

Wielowarstwowy szczególny charakter i wymowa tytułowej problematyki upoważniają do wyciągnięcia kilku ogólniejszych wniosków. Zasygnalizowany w tytule problem, czyli prześledzenie zmiany granicy węgiersko-jugosłowiańskiej po I wojnie światowej, stanowi tylko jeden z elementów szerszych rozważań nad przyczynami, przebiegiem i następstwami rozpadu Cesarstwa Austro-Węgierskiego, struktury państwowej zbudowanej na feudalnych, średniowiecznych zasadach narodowościowych, społecznych, politycznych i gospodarczych, obejmującej do 1918 r. większą część Europy Środkowej. 
Mapa 5. Rozpad Cesarstwa Austro-Węgierskiego na państwa narodowe po I wojnie światowej

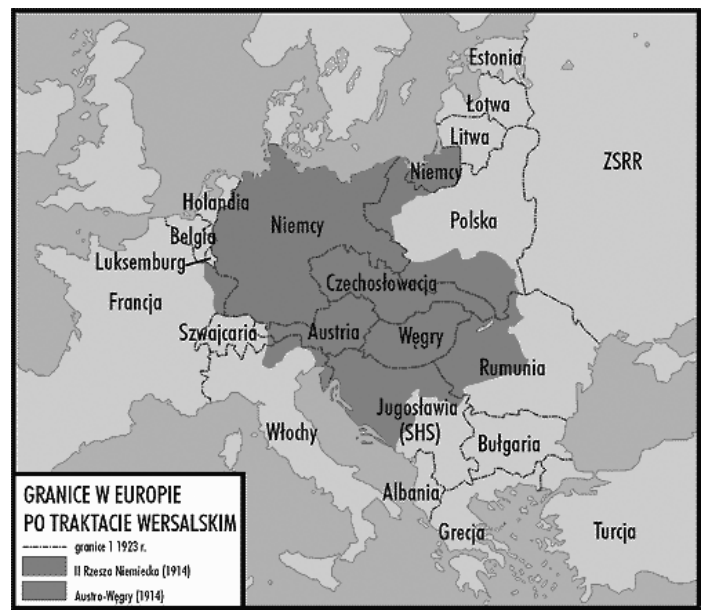

Źródło: http://www.google.pl,

Granice w Europie po Traktacie Wersalskim, encyklopedia.interia.pl/mapka.html? [29.07.2013].

Michály Károly, który w październiku 1918 r. utworzył rząd węgierski, przekształcając Węgry w republikę i usiłując wyprowadzić kraj z katastrofy, nazwał Królestwo Węgierskie państwem opartym na egoizmie jednej klasy. Ocenę Károlyego potwierdził w swoich spostrzeżeniach jeden z Polaków, przebywających na Węgrzech podczas II wojny światowej. W wywiadzie-ankiecie napisał on, że arystokracja węgierska jeszcze podczas II wojny światowej preferowała tradycyjny, na wpół feudalny sposób życia. Jej olbrzymimi majątkami zarządzała administracja, a pracowali w nich fornale żyjący ,jak w średniowieczu żyli chłopi pańszczyźniani”"89. Autor tej smutnej charakterystyki poziomu życia i stosunków społecznych określał Węgry jako: „Państwo, gdzie pewna warstwa społeczna trzyma kurczowo drugą warstwę po to, by z tej ostatniej korzystać i żyć, czerpiąc od życia tyle, ile się da"90.

Słowiańskie narody żyjące w Cesarstwie Austriacko-Węgierskim, Cesarstwie Niemieckim i Cesarstwie Rosyjskim marzyły o wolności. Przyniósł ją nieprzewidywalny przed I wojną światową splot okoliczności: klęska wszystkich trzech cesarstw na frontach wojennych, ich upadek pod wpływem rewolucji oraz aktywna postawa pragnących niepodległości narodów Europy Środkowej od Finlandii po Jugosławię.

Znany w okresie międzywojennym węgierski socjolog dr Ján Makkai w rozprawie o Węgrzech po I wojnie światowej napisał: „Trianoński traktat pokojowy pozostawił nowym Węgrom z grubsza podstawowe terytorium, które z etnograficznego punktu widzenia było zawsze wytapialnym piecem i europejską kolebką madziarskiej rasy. Štefan Széchenyi uważał Nizinę Węgierską (Alföld) za wielki ludowy rezer-

89 H. T. Csorba, Ziemia węgierska azylem Polaków 1939-1945, Warszawa 1985, s. 297-298.

90 Ibidem. (Ta słuszna ogólna ocena - którą podzielam - nie zmienia mojego szacunku dla postaci wyjątkowej, jakim był János Esterhazy, o którym pisałam w innych moich publikacjach). 
wat Madziarów, skąd dostawali zawsze nowe siły. [...] To ta węgierska nizina była przed tysiącem lat pierwszym środowiskiem osiedlenia Madziarów. [...] Według trianońskiego traktatu pokojowego były od Węgier oddzielone górskie kraje, większość miejskiej kultury, ale to pierwsze miejsce osiedlenia, europejskie środowisko Madziarów, zostało dla Madziarów"91.

Szczególne miejsce dla tych epokowych zmian w europejskim procesie dziejowym w okresie I wojny światowej należy przypisać Serbii. Jej olbrzymi wysiłek i determinacja - mimo wielkich strat przez cały okres wojny, uczestniczenie w zadaniu państwom centralnym decydującego ciosu przez Front Salonicki i w konsekwencji ostateczny triumf wojenny - odegrały bardzo ważną rolę w historii nie tylko słowiańskich narodów Bałkanów Zachodnich. Triumf Serbów zadecydował o rozpadzie Cesarstwa Austriacko-Węgierskiego, które zachodnie mocarstwa Ententy pragnęły utrzymać jako przeciwwagę dla opanowanej przez bolszewików Rosji. Postawa Serbów została zapamiętana przez przegranych.

W granicach państwa jugosłowiańskiego, funkcjonującego od 1 grudnia $1918 \mathrm{r}$. pod nazwą Królestwo SHS, obok Królestwa Serbii znalazły się należące w całości do byłego Królestwa Węgierskiego: Wojwodina (część Baranji, prawie cała Baczka i południowo-zachodni Banat), byłe Królestwo Chorwacji, Slavonii i Dalmacji z Međimurjem oraz Słowenia utworzona przez księstwa i regiony historyczne wchodzące do Cesarstwa Austriackiego, ale również oderwanego od Węgier Prekmurja. Przed państwami powstałymi w Europie Środkowej po upadku trzech cesarstw otworzyły się dla nich możliwości rozwoju cywilizacyjnego ${ }^{92}$, jakich niektóre z nich nie miały nigdy w swojej historii. Szczególnie złożone wyzwania stanęły przed narodami południowo-słowiańskimi, które z własnej woli postanowiły się zjednoczyć i podjąć próbę życia we wspólnym państwie. Aktualnym stał się również problem dostosowania i pogodzenia się z nową sytuacją przez narody, które do tego czasu panowały, ale wojnę przegrały i utraciły zorganizowane i rządzone przez nie imperia.

\section{Establishing the borders of Hungary with Croatia and Serbia after World War I}

In the previous volumes of "Research of Russia" I placed articles discussing briefly the issue of Slovakia and Prekmurje's separation from Hungary after World War I and as a result the establishment of the Slovak-Hungarian and Slovenian-Hungarian borders. The present publication is devoted to other significant results of the Habsburg Monarchy defeat during World War I and dissolution of Austria-Hungary. Significant participation of Serb divisions in victorious offensive of Salonika Front resulted in provisions of Belgrade Convention of November 13th 1918. They enabled Slavs National Assembly in Novi Sad accepting Declaration of annexation of Baranya, Bačka and Banat - the lands of Voyvodina to the Kingdom of Serbia. Defeat of the Habsburg Monarchy was also fortunate for Croats as they ended their dependence on the Hungarian Kingdom. In December 1918 Croats annexed Međimurje. Final detailed route of Hungarian-Yugoslav borders

\footnotetext{
${ }_{91}$ J. Makkai, A háború utáni Magyarország, wyd. II, Budapešt 1937, s. 24-25.

92 Autoportret - A. Szczerski, Nowa Europa Środkowo-Wschodnia 1918-1939, Katalog Czasopism Kulturalnych, 3.04.2011.
} 
was included in a Treaty signed in Trianon on June 4th 1920. It also considered the position of scattered on Yugoslav-Hungarian borders Slovaks, Bunjevci, Šokci, Krasovians - few yet very active Slav minorities.

\section{Установление границ Венгрии с Хорватией и Сербией после I мировой войны}

В предыдущих томах журнала я поместила статьи, в которых вкратце обсуждалось оторвание от Венгрии после I мировой войны Словакии и Прекмурья, а впоследствии формирование словако-венгерской и словено-венгерской границ. Нынешняя публикация посвящена очередным важным последствиям поражения Габсбургской монархии в I мировой войне и распада Австро-Венгрии. Значительное участие сербских дивизий в победном наступлении Салоникского фронта принесло плоды в виде постановлений Белградской конвенции от 13 ноября 1918 г. Они предоставили возможность Национальному собранию славян в Нови-Саде принять декларацию о присоединении Бараньи, Бачки и Баната, те. регионов Воеводины, к Сербскому королевству. Поражением монархии Габсбургов воспользовались также Хорваты, прекращая многовековую зависимость от Венгерского королевства. В декабре 1918 г. Хорваты присоединили к своему государству также Медимурье. Окончательные и подробные венгеро-югославские границы были определены в договоре, подписанном в Трианоне 4 июня 1920 г. Он учитывал также позицию разбросанных в югославо-венгерской пограничной зоне Словаков, Буньевцев, Шокцев и Карашевцев немногочисленных, но очень активных славянских меньшинств. 